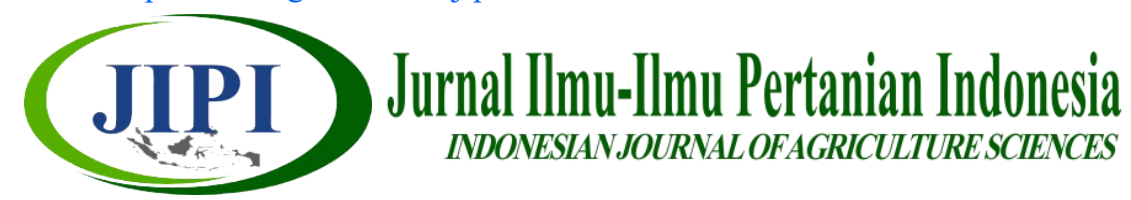

\title{
RESPON PERTUMBUHAN DAN HASIL LIMA GENOTIPE PADI F1 TERHADAP PUPUK ORGANIK TANDAN KOSONG KELAPA SAWIT (TKKS) PADA TANAH ULTISOL
}

\author{
David Khairullah Hadi ${ }^{1}$, Reny Herawati ${ }^{1 *}$,Widodo ${ }^{1}$, Helfi Eka Saputra ${ }^{1}$, Mukhtasar ${ }^{1}$, \\ Eko Suprijono 1 \\ ${ }^{1}$ Program Studi Agroekoteknologi, Fakultas Pertanian Universitas Bengkulu \\ * Corresponding Author: reny.herawati@unib.ac.id
}

\begin{abstract}
[RESPONSE OF GROWTH AND YIELD OF FIVE RICE F1 GENOTIPE ON THE ORGANIC FERTILIZER OF PALM OIL BUNCHES ON ULTISOL].Oil Palm Bunches(OPB) are solid waste potential as organic fertilizer to improve soil physical, biological and chemical properties, especially on ultisol soils for rice development. This research was conducted in August - November 2019 in Padang Harapan, Bengkulu City. The materials used were F1 rice seeds, OPB organic fertilizer. The experimental design was a factorial Randomized Complete Block Design (CRBD) with 2 factors. The first factor was 5 hybrid genotypes (F1), namely, Kuning x Inpago5, Kuning x Inpago9, Kuning x Inpago6, Arang x Inpago8, and Kuning x Salumpikit. The second factor wass the dosage of OPB, namely 0 (control), 10 tonnes/ha, 15 tonnes/ha, and 20 tonnes/ha, the experiment was repeated 3 times. The variables observed were plant height, number of productive tillers, flowering age, harvest age, total number of fill grains, number of filled grains, number of empty grains, 1000 grain weight, and grain weight/hill. The results showed that there was an interaction between genotype and OPB on the number of tillers. The interaction between the Kuning x Salumpikit genotypes and 10 tonnes/ha of organic fertilizer produced the largest number of tillers. Genotype G3 (Kuning $\mathrm{x}$ Inpago6) produced the best rice growth and yield. In this study, the optimum point for OPB fertilization on growth and yield of the five genotypes tested had not been obtained.
\end{abstract}

Keyword: genotype, F1, OPB palm oil waste, growth, yield, ultisol

\begin{abstract}
ABSTRAK
Tandan Kosong Kelapa Sawit (TKKS) adalah limbah padat yang sangat potensial di jadikan kompos yang dapat memperbaiki sifat fisik, biologi dan kimia tanah terutama pada tanah ultisol untuk pengembangan tanaman padi. Penelitian ini dilaksanakan pada bulan Agustus - November 2019 di Padang Harapan Kota Bengkulu.Bahan yang di gunakan adalah benih padi F1, pupuk organik TKKS. Rancangan percobaan yang digunakan adalah Rancangan Acak Kelompok Lengkap (RAKL) faktorial dengan 2 faktor. Faktor Pertama adalah 5 genotipe hibrida (F1) yaitu, Kuning x Inpago5, Kuning x Inpago9, Kuning x Inpago6, Arang x Inpago8, dan Kuning x Salumpikit. Faktor kedua adalah dosis TKKS, yaitu 0 (kontrol), 10 ton/ha, 15 ton/ha, dan 20 ton/ha. Percobaan diulang 3 kali, sehingga terdapat 60 satuan percobaan. Variabel yang diamati adalah tinggi tanaman, jumlah anakan produktif, umur berbunga, umur panen, jumlah gabah total, jumlah gabah isi, jumlah gabah hampa, bobot 1000 butir, dan bobot gabah/rumpun. Hasil penelitian menunjukkan terdapat interaksi antara genotipe dengan TKKS terhadap jumlah anakan.Interaksi antara genotipe Kuning x Salumpikit dan 10 ton/ha pupuk organik menghasilkan jumlah anakan padi terbanyak. Genotipe G3(Kuning x Inpago6) menghasilkan pertumbuhan dan hasil padi terbaik. Pada penelitian ini belum diperoleh titik optimum pemupukan TKKS terhadap pertumbuhan dan hasil lima genotipe yang diuji.
\end{abstract}

Kata kunci: genotipe, F1, limbah sawit TKKS, pertumbuhan, hasil, ultisol 


\section{PENDAHULUAN}

Tanaman padi (Oryza sativa L.) merupakan tanaman pangan yang memiliki peranan penting di Indonesia. Sebagian besar penduduk Indonesia menggunakan padi sebagai bahan pangan utama.Padi memiliki kandungan karbohidrat yang baik untuk memenuhi kebutuhan energi bagi manusia. Sekitar 1.750 juta jiwa dari sekitar 3 miliar penduduk Asia termasuk 200 juta penduduk Indonesia menggantungkan kebutuhan kalorinya dari beras (Makarim \& Suhartatik, 2006). Luas panen padi di Indonesia pada tahun 2018 adalah yang 11.377.934,44 ha mampu memproduksi padi sebanyak 59.200.533,72 ton dengan produktivitas sebesar 5,2 ton/ha. Namun pada 2019 luas panen menurun menjadi 10.677.887,15 ha dengan produksi padi sebesar 54.604.033,34 ton dan produktivitas sebesar 5,11 ton/ha (BPS, 2020). Penggunaan pupuk sintentik secara terus menerus dapat mengakibatkan kerusakan pada tanah.Astiningrum (2005) menyatakan bahwa pemakaian pupuk kimia secara berlebihan dapat menyebabkan residu yang berasal dari zat pembawa (carier) pupuk nitrogen tertinggal dalam tanah sehingga akan menurunkan kualitas dan kuantitas hasil pertanian.

Ultisol merupakan salah satu jenis tanah di Indonesia yang mempunyai sebaran luas mencapai 45.794 .000 ha atau sekitar 25\% dari total luas daratan Indonesia. Namun demikian, ultisol merupakan tanah yang memiliki masalah keasaman tanah, bahan organik rendah dan nutrisi makro rendah dan memiliki ketersediaan P sangat rendah (Fitriatin et al., 2014). Ultisol memiliki kapasitas tukar kation (KTK), kejenuhan basa (KB), retensi N, P, $\mathrm{K}$ dan C-organik rendah sampai dengan sangat rendah, dan kandungan aluminium (kejenuhan $\mathrm{Al}$ ) tinggi, serta $\mathrm{pH}$ masam (Syahputra et al., 2015). Hal ini mengindikasikan bahwa tanah sudah mengalami pelapukan lanjut sehingga kesuburan tanah menjadi rendah (Kusumastuti, 2014).

Penambahan bahan organik pada tanah ultisol merupakan salah satu upaya yang dapat dilakukan untuk mengatasi masalah defisiensi hara dalam tanah. Bahan organik dalam proses dekomposisinya akan melepaskan asam-asam organik yang dapat mengikat Al dan membentuk senyawa kompleks, sehingga Al menjadi tidak larut (Tan, 2010). Menurut Siregar et al. (2017) bahwa bahan organik mampu meningkatkan $\mathrm{pH}$ tanah, P-tersedia, KTK serta serta menurunkan Al-dd tanah. Selain itu, Syahputra et al. (2016) melaporkan bahwa pemberian amelioran berupa bahan organik mampu meningkatkan waktu panen, jumlah anakan produktif, bobot gabah kering dan bobot kering tanaman padi gogo pada ultisol. Hasil penelitian Gusmiatun \& Marlina (2018) menunjukkan bahwa penggunaan pupuk organik dapat mengurangi pemakaian pupuk anorganik/kimia. Kombinasi pupuk anorganik $50 \%+$ organik $50 \%$, dapat meningkatkan hasil tanaman padi sebesar $23.8 \%$ dibandingkan tanpa menambahkan pupuk organik.
Tandan Kosong Kelapa Sawit (TKKS) adalah limbah padat yang dihasilkan dari proses pengolahan kelapa sawit, sangat potensial di jadikan komposdan di harapkan dapat memperbaiki sifat fisik, biologi dan kimia tanah. Toiby et al. (2015), melaporkan bahwa kompos TKKS mengandung hara N-Total; 6,79\% $\mathrm{P}_{2} \mathrm{O}_{5} ; 3,13 \% \mathrm{~K}_{2} \mathrm{O} ; 8,33 \%$ dengan $\mathrm{pH} 9,59$. Andri et al., (2016) dalam penelitiannya memberikan campuran 50 g kompos TKKS dapat memperbaiki sifat fisik tanah seperti perbaikan struktur tanah, daya simpan air, pertukaran udara/aerasi tanah. Tandan kosong kelapa sawit dapat dimanfaatkan sebagai sumber pupuk organik yang memiliki kandungan unsur hara yang dibutuhkan oleh tanah dan tanaman. Tandan kosong kelapa sawit mencapai 23\% dari jumlah pemanfaatan limbah kelapa sawit, dapat digunakan sebagai alternatif sumber pupuk organik yang akan memberikan manfaat lain dari sisi ekonomi. Keunggulan kompos TKKS adalah kandungan kalium yang tinggi, akan memperkaya unsur hara yang ada di dalam tanah, dan mampu memperbaiki sifat fisik, kimia dan biologi. Kadar hara kompos TKKS mengandung $\mathrm{N}$ total $(1,91 \%), \mathrm{K}(1,51 \%), \mathrm{Ca}(0,83 \%), \mathrm{P}(0,54 \%)$, $\mathrm{Mg}(0,09 \%)$, Corganik (51,23\%), $\mathrm{C} / \mathrm{N}$ ratio $26,82 \%$, dan $\mathrm{pH} 7,13$. Hasil analisis kadar hara kompos tandan kosong kelapa sawit adalah N (3,62\%), P (0,94\%) dan K (0,62\%) (Hayat, 2014).

Penggunaan varietas unggul padi yang adaptif pada tanah masam dapat meningkatkan produksi dengan biaya yang relatif murah karena varietas tersebut mampu mempertahankan produktivitasnya tanpa pemberian kapur yang terus menerus. Pengembangan varietas unggul yang mampu beradaptasi baik pada lingkungan tercekam (abiotik dan biotik) melalui pemuliaan tanaman perlu dilakukan (Subekti, 2011).Toleransi tanaman terhadap aluminium merupakan faktor yang penting untuk adaptasi pada tanah masam (Utama, 2008). Hal ini karena, tingginya kadar aluminium pada tanah ultisol dapat menghambat proses metabolisme dan pertumbuhan tanaman, akan tetapi sampai ambang tertentu pengaruh dari aluminium dapat ditoleransi oleh tanaman yang toleran (Kasim, 2000). Saat ini varietas padi toleran cekaman lingkungan abiotik dan biotik masih sangat kurang, terutama varietasi yang mampu beradaptasi pada lingkungan yang spesifik lokasi (Herawati et al.,2009; Utama et al.,2009). Oleh karena itu, upaya memperoleh genotipe-genotipe padi unggul pada lingkungan tanah masam seperti ultisol perlu dilakukan, terutama responnya terhadap pertumbuhan dan daya hasil pada pemberian bahan organik TKKS.

\section{METODE PENELITIAN}

Penelitian ini dilaksanakan pada bulan Agustus - November 2019 di Padang Harapan Kota Bengkulu, dengan ketinggan tempat $17 \mathrm{~m}$ dpl. Bahan yang di gunakan adalah benih padi F1, pupuk organik TKKS, polibag berukuran $45 \mathrm{~cm} \mathrm{x} 40 \mathrm{~cm}$, plastik kedap air, bam- 
bu, batang kayu, waring, jaring, dan paku. Alat yang digunakan dalam penelitian ini yaitu cangkul, timbangan, penggaris, parang dan ayakan.

Penelitian ini menggunakan Rancangan Acak Kelompok Lengkap (RAKL) faktorial dengan 2 faktor. Faktor pertama ialah 5 genotipe hibrida (F1) padi sawah yaitu, $\mathrm{G}_{1}$ (Kuning x Inpago 5), $G_{2}$ (Kuning x Inpago 9), $G_{3}$ (Kuning $x$ Inpago 6), $\mathrm{G}_{4}$ (Arang $\mathrm{x}$ Inpago 8), dan $\mathrm{G}_{5}$ (Kuning $x$ Salumpikit). Sedangkan faktor kedua adalah dosis pupuk organik TKKS, yaitu $\mathrm{T}_{0}=0 \mathrm{~g} /$ polibag, $\mathrm{T}_{1}=50 \mathrm{~g} /$ polibag (setara $15 \mathrm{ton} / \mathrm{ha}$ ), $\mathrm{T}_{2}=75 \mathrm{~g} /$ polibag (setara 15 ton $/ \mathrm{ha}$ ), dan $\mathrm{T}_{3}=100 \mathrm{~g} / \mathrm{polibag}$ (setara 20 ton/ha), sehingga diperoleh 20 kombinasi perlakuan. Percobaan diulang 3 kali, sehingga terdapat 60 satuan percobaan. Setiap percobaan terdapat 3 sampel tanaman, sehingga terdapat 180 polibag unit percobaan.

Benih disemai terlebih dahulu dalam pot sampai bibit berumur 14 hari. Pupuk organik TKKS diberikan sesuai dengan dosis perlakuan yaitu dosis $0 \mathrm{~g}$ /polibag, 50 g/polibag, 75 g/polibag, dan 100 g/polibag. Pemberian pupuk organik TKKS dilakukan dengan cara memasukkan pupuk ke dalam polibag yang telah berisi tanah. Selanjutnya diaduk agar tecampur dengan tanah dalam polibag. Sebelum melakukan penanaman, tanah diberi pupuk dasar pupuk Urea, $\mathrm{KCl}$, dan TSP masing-masing 3 $\mathrm{g} /$ polibag, kecuali urea diberikan dua kali yaitu sebelum penanaman dan 3 minggu setelah tanam. Penanaman dilakukan setelah bibit berumur 14 hari. Penanaman dilakukan dalam polibag yang telah berisi media tanam sesuai perlakuan dengan cara membuat lubang tanam dengan kedalaman $\pm 5 \mathrm{~cm}$. Bibit yang ditanam pada masing-masing polibag sebanyak satu bibit.

Pemeliharaan meliputi penyulaman jika terdapat bibit yang mati/tidak tumbuh, dari percobaan ini penyulaman kurang dari $10 \%$ dari benih yang tidak tumbuh atau pertumbuhannya kurang baik. Penyiangan dilakukan dengan cara mencabut gulma jika ada yang tumbuh dalam polibag. Penambahan air diperlukan jika tidak ada hujan, dan media harus selalu terjaga dalam kondisi jenuh air. Pengendalian hama dan penyakit dilakukan secara fisik/mekanis, sedangkan upaya pencegahan dilakukan dengan memasang waring dan jaring untuk menghindari hama tikus, burung, dan kepik/walang sangit. Penen dilakukan jika malai telah masak penuh, berwarna kuning keemasan dan telah mencapai lebih dari $90 \%$. Pengamatan dilakukan terhadap semua sampel, yaitu tiga sampel tanaman setiap unit percobaan. Variabel yang diamati adalah tinggi tanaman, jumlah anakan total, jumlah anakan produktif, jumlah anakan non produktif, umur berbunga, umur panen, jumlah gabah total, jumlah gabah isi, jumlah gabah hampa, bobot 100 butir, dan bobot gabah isi/malai.

Data penelitian yang diperoleh dianalisis statistik menggunakan uji $\mathrm{F}$ pada taraf $5 \%$. Variabel yang menunjukkan perbedaan nyata antar genotipe maka dilanjutkan dengan DMRT taraf 5\%, sedangkan in- teraksi antara dosis TKKS dengan genotipe dilakukan dengan analisis regresi sederhana.

\section{HASIL DAN PEMBAHASAN}

Hasil analisis ragam menunjukkan bahwa interaksi antara genotipe dan pupuk organik memberikan pengaruh nyata terhadap jumlah anakan padi, namun berpengaruh tidak nyata terhadap tinggi tanaman, umur berbunga, umur panen, jumlah gabah isi, jumlah gabah hampa, jumlah gabah total, bobot gabah/ rumpun, dan bobot 1000 bulir (Tabel 1). Genotipe padi memberikan pengaruh nyata terhadap tinggi tanaman, dan jumlah anakan, serta berpengaruh nyata terhadap jumlah gabah isi, dan bobot 1000 bulir, namun berpengaruh tidak nyata terhadap umur berbunga, umur panen, jumlah gabah isi, jumlah gabah total, dan bobot gabah/ rumpun (Tabel 1). Sedangkan pupuk organik memberikan pengaruh nyata terhadap bobot gabah/rumpun, serta berpengaruh nyata terhadap jumlah anakan, umur berbunga, dan jumlah gabah isi, namun berpengaruh tidak nyata terhadap tinggi tanaman, umur panen, jumlah gabah hampa, jumlah gabah total, dan bobot 1000 bulir (Tabel 1).

Tabel 1. Hasil analisis ragam pengaruh genotipe dan pupuk organik TKKS terhadap pertumbuhan dan hasil padi

\begin{tabular}{|l|c|c|c|c|}
\hline \multirow{2}{*}{ Variabel Pengamatan } & \multicolumn{3}{|c|}{ F-hitung } & \multirow{2}{*}{ KK } \\
\cline { 2 - 4 } & Interaksi & Genotip & $\begin{array}{c}\text { Pupuk } \\
\text { Organik }\end{array}$ \\
\hline Tinggi tanaman & $0,86^{\text {ns }}$ & $4,07^{*}$ & $1,36^{\text {ns }}$ & 2,42 \\
\hline Jumlah anakan produktif & $7,96^{*}$ & $7,35^{*}$ & $3,56^{*}$ & 4,35 \\
\hline Umur berbunga & $0,92^{\text {ns }}$ & $0,51^{\text {ns }}$ & $2,96^{*}$ & 2,36 \\
\hline Umur panen & $1,08^{\text {ns }}$ & $1,01^{\text {ns }}$ & $2,67^{\text {ns }}$ & 1,23 \\
\hline Jumlah gabah isi & $0,50^{\text {ns }}$ & $2,66^{*}$ & $4,09^{*}$ & 7,81 \\
\hline Jumlah gabah hampa & $0,71^{\text {ns }}$ & $0,63^{\text {ns }}$ & $0,66^{\text {ns }}$ & 17,13 \\
\hline Jumlah gabah total & $0,50^{\text {ns }}$ & $1,44^{\text {ns }}$ & $2,08^{\text {ns }}$ & 9,5 \\
\hline Bobot gabah/rumpun & $0,51^{\text {ns }}$ & $0,22^{\text {ns }}$ & $5,37^{*}$ & 1,42 \\
\hline Bobot 1000 bulir & $1,44^{\text {ns }}$ & $3,66^{*}$ & $0,22^{\text {ns }}$ & 0,46 \\
\hline Keterangan: $*$ berpengaruh nyata $;$ ns $=$ berpengaruh tidak nyata \\
\hline KK = koefisien keragaman
\end{tabular}

Dosis pupuk organik membentuk hubungan linear positif dengan jumlah anakan padi pada genotipe $\mathrm{G}_{2}$ dan $\mathrm{G}_{4}$ dengan persamaan secara berturutturut $\mathrm{Y}_{\mathrm{G} 2}=18,889+0,0001 \mathrm{x}$ dan $\mathrm{Y}_{\mathrm{G} 4}=18,267+$ 0,08x. Pola linear positif menunjukkan bahwa peningkatan dosis pupuk organik pada genotipe $G_{2}$ dan $\mathrm{G}_{4}$ akan diikuti dengan meningkatnya jumlah anakan padi (Gambar 1). Hal ini berarti bahwa genotipe $\mathrm{G}_{2}$ dan $\mathrm{G}_{4}$ masih merespon positif terhadap peningkatan dosis 
pupuk organik. Semakin tinggi dosis pupuk organik yang diberikan maka semakin banyak suplai unsur hara pada tanaman sehingga jumlah anakan semakin banyak. Hasil penelitian ini sejalan dengan penelitian Ginting et al. (2015) yang menunjukkan bahwa pemberian pupuk organik dapat meningkatkan jumlah anakan dan jumlah anakan produktif. Menurut Syahril et al. (2017) dan Hepriyani et al. (2016) bahwa peningkatan unsur $\mathrm{N}$ terbukti meningkatkan

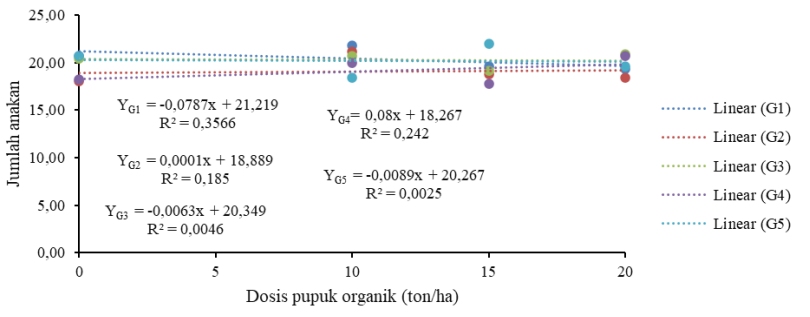

jumlah anakan padi.

Gambar 1. Hubungan interaksi antara dosis pupuk organik TKKS terhadap jumlah anakan produktif pada lima genotipe F1

Hasil berbeda didapat dari hubungan antara pupuk organik dan jumlah anakan padi pada genotipe $G_{1}$, $\mathrm{G}_{3}$, dan $\mathrm{G}_{5}$ yang membentuk pola linear negatif dengan persamaan secara berturut-turut adalah $\mathrm{Y}_{\mathrm{G} 1}=$ $21,219-0,0787 \mathrm{x}, \mathrm{Y}_{\mathrm{G} 3}=20,349-0,0063 \mathrm{x}$, dan $\mathrm{Y}_{\mathrm{G} 5}=$ 20,267-0,0089x. Hal ini diduga karena pemberian 5 ton/ha pupuk organik sudah mampu mencukupi kebutuhan nutrisi tanaman bagi padi genotip $\mathrm{G}_{1}, \mathrm{G}_{3}$, dan $\mathrm{G}_{5}$, sehingga peningkatan dosis di atas 5 ton/ha justru menurunkan jumlah anakan padi. Jumlah anakan akan maksimal apabila tanaman memiliki sifat genetik yang baik ditambah dengan keadaan lingkungan yang menguntungkan atau sesuai dengan pertumbuhan dan perkembangan tanaman. Secara genetik jumlah anakan padi ditentukan oleh jenis varietas tanaman. Namun demikian, selain ditentukan oleh varietas jumlah anakan juga dipengaruhi oleh kondisi lingkungan. Varietas masing-masing mempunyai sifat yang ber-beda (Sitinjak \& Idwar, 2015). Selain faktor genetik, faktor lingkungan dan sistem budidaya juga mem-pengaruhi pertumbuhan dan perkembangan tanaman. Perbedaan jumlah anakan masing-masing varietas diduga karana pengaruh faktorfaktor tersebut. Herawati et al. (2019) menyatakan bahwa jumlah anakan produktif merupakan salah satu karakteristik agronomi penting dan yang merupakan penentu identitas genotipe. Hal tersebut sejalan dengan hasil penelitian dari Anhar et al. (2016) yang menunjukkan bahwa jumlah anakan dan tinggi tanaman yang berbeda disebabkan setiap varietas memiliki sifat gen yang berbeda-beda.

Hasil penelitian menunjukkan bahwa komponen tinggi tanaman, jumlah anakan, jumlah gabah isi, dan bobot 1000 bulir dikendalikan oleh genetik. Sejalan dengan hasil penelitian Herawati et al. (2017) yang menunjukkan bahwa tinggi tanaman, anakan produktif, panjang malai, jumlah butir isi, jumlah butir hampai dan bobot butir memiliki keragaman genetik yang luas.

Genotipe $\mathrm{G}_{3}$ secara rata-rata menghasilkan tinggi tanaman tertinggi yang berbeda tidak nyata dengan genotip $G_{1}$, namun berbeda nyata dengan genotip lainnya. Sedangkan $\mathrm{G}_{2}$ menghasilkan tinggi tanaman terendah yang berbeda tidak nyata dengan $G_{1}, G_{2}$, $\mathrm{G}_{4}$, dan $\mathrm{G}_{5}$, namun berbeda nyata dengan $\mathrm{G}_{3}$ (Tabel 2). Tinggi tanaman pada genotipe $\mathrm{G}_{3}$ rata-rata $117,39 \mathrm{~cm}$ atau lebih tinggi 3,60\% dari tinggi tanaman pada genotip $G_{2}$ yaitu $113,31 \mathrm{~cm}$. Perbedaan tinggi tanaman masing-masing genotipe yang diuji disebabkan adanya perbedaan genetik masing-masing genotipe, yang memiliki ciri dan sifat khusus yang berbeda. Herawati et al. (2009) dalam penelitiannya menyatakan bahwa tinggi tanaman merupakan karakter agronomi penting dan dapat dijadikan identitas penting suatu genotip. Nazirah \& Damanik (2015) menambahkan bahwa perbedaan susunan genetik merupakan salah satu faktor yang menyebabkan penampilan tanaman beragam dalam hal ini adalah tinggi tanaman.

Jumlah gabah isi terbanyak dihasilkan oleh genotip $\mathrm{G}_{3}$ yang berbeda nyata dengan genotip lainnya. Sedangkan genotip $\mathrm{G}_{1}$ menghasilkan jumlah gabah isi terendah yang berbeda nyata dengan genotipe lainnya. Genotip $\mathrm{G}_{3}$ menghasilkan jumlah gabah isi sebanyak 316,03 biji atau lebih banyak 10,57\% dari jumlah gabah isi yang dihasilkan genotipe $G_{1}$ yaitu sebanyak 285,83 biji (Tabel 2). Hal ini menunjukkan bahwa genotipe $\mathrm{G}_{3}$ memiliki potensi hasil lebih baik daripada genotipe lainnya. Hasil penelitian Herawati et al. (2019) menunjukkan bahwa jumlah butir isi dikendalikan oleh banyak gen. Sejalan dengan hasil penelitian Ikhwani \& Rustiati (2018) bahwa varietas padi berpengaruh nyata terhadap jumlah gabah isi. Varietas padi yang memiliki tingkat adaptasi dan ketahanan lebih baik akan menghasilkan jumlah gabah isi lebih banyak.

Tingginya jumlah gabah isi pada genotipe $\mathrm{G}_{3}$ dikarenakan memiliki jumlah anakan lebih banyak. Sejalan dengan hasil penelitian Herawati et al. (2019) bahwa jumlah anakan berkorelasi positif dengan jumlah gabah isi.Semakin banyak jumlah anakan padi, maka semakin banyak jumlah gabah isinya. Selain itu, banyaknya jumlah gabah isi pada genotipe $\mathrm{G}_{3}$ disebabkan menghasilkan tinggi tanaman lebih tinggi dibandingkan dengan genotipe lainnya.Tinggi tanaman mengindikasikan besarnya proporsi tajuk atau biomassa sebagai source. Tajuk merupakan bagian dari tanaman yang berperan pada proses fotosintesis, semakin banyak fotosintat yang dihasilkan semakin besar pengaruhnya terhadap hasil gabah.

Hasil penelitian menunjukkan bahwa genotipe $\mathrm{G}_{2}$ menghasilkan bobot 1000 biji terberat yang berbeda tidak nyata dengan genotipe $\mathrm{G}_{3}, \mathrm{G}_{4}$, dan $\mathrm{G}_{5}$, 
namun berbeda nyata dengan $\mathrm{G}_{1}$. Sedangkan genotip $\mathrm{G}_{1}$ menghasilkan bobot 1000 biji terendah yang berbeda tidak nyata dengan genotipe $\mathrm{G}_{5}$, namun berbeda nyata dengan genotip $\mathrm{G}_{2}, \mathrm{G}_{3}$, dan $\mathrm{G}_{4}$. Bobot 1000 biji pada genotipe $\mathrm{G}_{2}$ adalah seberat $17,46 \mathrm{~g}$ atau lebih tinggi $0,69 \%$ daripada bobot 1000 biji yang dihasilkan $\mathrm{G}_{1}$ yaitu seberat 17,34 g (Tabel 2). Perbedaan bobot 1000 biji masing-masing genotip disebabkan setiap genotipe memiliki karakteristik yang berbeda dari hasil persilangan tetuanya. Hasil penelitian Siregar et al. (2013) juga menunjukkan bahwa varietas memiliki pengaruh nyata terhadap bobot 1000 biji. Masing-masing varietas akan menghasilkan bobot 1000 biji yang berbeda-beda sesuai dengan deskripsinya. Karakter panjang malai dan bobot 1.000 butir dikontrol oleh sifat genetik, sehingga perbedaan karakter tersebut merupakan ekspresi dari sifat genetik (Herawati et al., 2010).

Tabel 2. Pengaruh genotip padi terhadap tinggi tanaman, jumlah anakan, jumlah gabah isi dan bobot 1000 bulir

\begin{tabular}{|c|c|c|c|}
\hline Genotip & $\begin{array}{c}\text { Tinggi tanaman } \\
(\mathrm{cm})\end{array}$ & $\begin{array}{c}\text { Jumlah } \\
\text { gabah isi } \\
(\mathrm{biji})\end{array}$ & $\begin{array}{c}\text { Bobot } 1000 \\
\text { bulir }(\mathrm{g})\end{array}$ \\
\hline $\mathrm{G}_{1}$ & $115,50 \mathrm{ab}$ & $285,83 \mathrm{c}$ & $17,34 \mathrm{~b}$ \\
\hline $\mathrm{G}_{2}$ & $113,31 \mathrm{~b}$ & $303,17 \mathrm{~b}$ & $17,46 \mathrm{a}$ \\
\hline $\mathrm{G}_{3}$ & $117,39 \mathrm{a}$ & $316,03 \mathrm{a}$ & $17,43 \mathrm{a}$ \\
\hline $\mathrm{G}_{4}$ & $114,11 \mathrm{~b}$ & $304,97 \mathrm{~b}$ & $17,44 \mathrm{a}$ \\
\hline $\mathrm{G} 5$ & $114,03 \mathrm{~b}$ & $308,69 \mathrm{~b}$ & $17,41 \mathrm{ab}$ \\
\hline Keterangan : Angka-angka yang diikuti oleh huruf yang sama \\
\hline pada kolom yang sama berbeda tidak nyata pada DMRT 5\% \\
\hline $\mathrm{G}_{1}=$ Kuning x Inpago 5, $\mathrm{G}_{2}=$ Kuning x Inpago 9 \\
\hline \\
\hline $\mathrm{G}_{3}=$ Kuning x Inpago, $\mathrm{G}_{4}=$ Arang x Inpago 8, \\
\hline \\
\hline
\end{tabular}

Dosis pupuk organik membentuk hubungan linear negatif dengan umur berbunga padi yang digambarkan dengan persamaan $\mathrm{Y}=59,109-0,063 \mathrm{x}$ dan nilai $\mathrm{R}^{2}=0,770$. Koefisien determinasi $\left(\mathrm{R}^{2}\right)$ sebesar 0,770 berarti bahwa persamaan regresi yang terbentuk mampu menggambarkan hubungan antara dosis pupuk organik dan umur berbunga sebesar $77 \%$. Pola hubungan antara dosis pupuk organik dan umur berbunga disajikan pada Gambar 2 .

Pola linear negatif berarti bahwa peningkatan dosis pupuk organik akan diiktui dengan menurunnya atau semakin cepatnya tanaman padi berbunga. Hal tersbut karena pemberian pupuk organik berupa TKKS mampu meningkatkan ketersediaan hara terutama $\mathrm{P}$ terhadap tanaman padi. Peningkatan kandungan $\mathrm{P}$ dalam tanah akan menyebabkan tanaman padi lebih cepat berbunga. Menurut Mashfufah \&
Prasetya (2019) bahwa penambahan TKKS mampu meningkatkan ketersediaan $\mathrm{P}$ karena adanya proses dekomposisi.

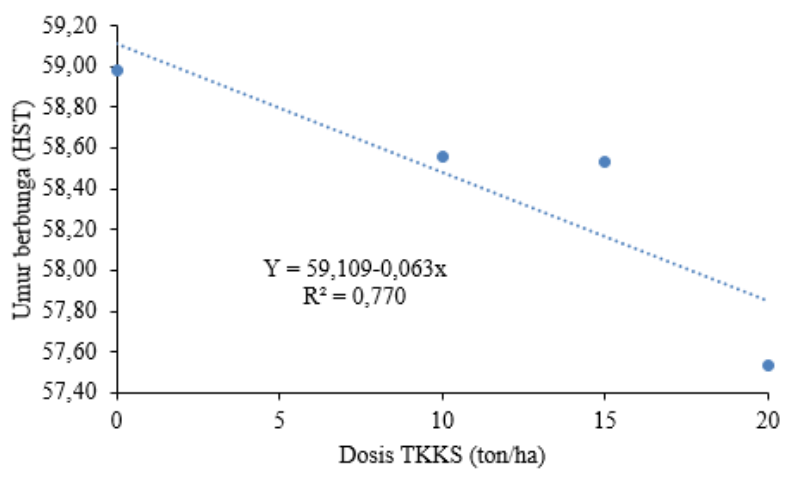

Gambar 2. Hubungan antara dosis pupuk organik TKKS dan umur berbunga

Hasil penelitian menunjukkan bahwa dosis pupuk organik dan jumlah gabah isi membentuk hubungan linear positif dengan jumlah gabah isi dengan persamaan $\mathrm{Y}=287,64+1,4312 \mathrm{x}$ dan nilai koefisien determinasi $\left(R^{2}\right)=0,9745$ (Gambar 3). Nilai koefisien determinasi $\left(\mathrm{R}^{2}\right)$ sebesar 0,9745 berarti bahwa persamaan regresi yang terbentuk mampu menggambarkan hubungan antara dosis pupuk organik dan jumlah gabah isi sebesar 97,45\%.

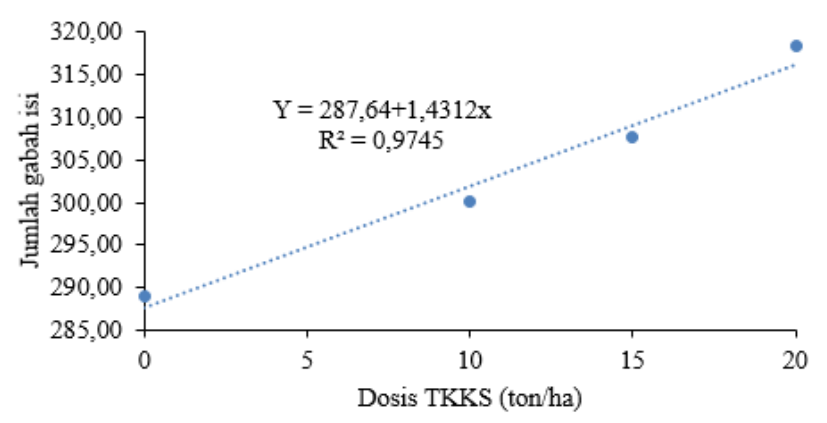

Gambar 3. Hubungan antara dosis pupuk organik TKKS dan jumlah gabah isi

Pola linear positif berarti bahwa peningkatan dosis pupuk organik akan meningkatkan jumlah gabah isi padi. Hal ini karena semakin tinggi dosis pupuk organik yang diberikan maka semakin meningkatkan kesuburan tanahnya. Proses dekomposisi masingmasing bahan organik yang menghasilkan senyawa humik yang menyumbangkan koloid-koloid tanah sehingga KTK tanah akan meningkat. Terjadinya peningkatan KTK disebabkan bahan organik berpengaruh terhadap bertambahnya muatan negatif koloid tanah. Muatan negatif ini berasal dari gugus karboksil $(\mathrm{COOH})$ dan hidroksil $(\mathrm{OH})$ yang terdapat dalam senyawa organik (Siregar et al., 2017). Peningkatan KTK akan menyebabkan unsur-unsur hara seperti $\mathrm{P}$ 
berada dalam bentuk yang lebih tersedia bagi tanaman. Pemberian pupuk organik dapat meningkatkan jumlah anakan, jumlah anakan produktif dan jumlah bulir/malai serta produksi gabah/petak (Ginting et al., 2015).

Berdasarkan hasil penelitian terlihat bahwa dosis pupuk organik dan bobot gabah/rumpun membentuk hubungan linear positif dengan jumlah gabah isi dengan persamaan $\mathrm{Y}=31,471+0,0253 \mathrm{x}$ dan nilai koefisien determinasi $\left(\mathrm{R}^{2}\right)=0,6429$ (Gambar 4). Nilai koefisien determinasi $\left(\mathrm{R}^{2}\right)$ sebesar 0,6429 berarti bahwa persamaan regresi yang terbentuk mampu menggambarkan hubungan antara dosis pupuk organik dan bobot gabah/rumpun sebesar 64,29\%.

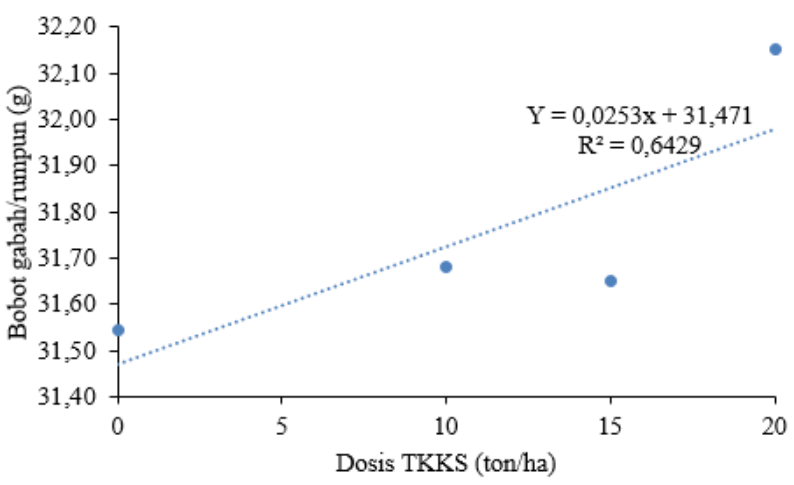

Gambar 4. Hubungan antara dosis pupuk organik TKK dan bobot gabah isi/rumpun

Pola linear positif berarti bahwa peningkatan dosis pupuk organik akan meningkatkan bobot gabah/rumpun. Hal ini karena pemberian bahan organik berupa kompos dapat meningkatkan dan menyediakan unsur hara baik makro maupun mikro bagi tanaman. Unsur hara digunakan oleh tanaman dalam proses pertumbuhan dan perkembangan tanaman. Hasil tanaman berkaitan dengan cara bagaimana sumber daya dipergunakan untuk menghasilkan sumber daya atau produk. Hasil padi gogo merupakan akumulasi fotosintat pada tanaman padi gogo.

Tandan kosong kelapa sawit adalah kompos dari limbah organik hasil pabrik kelapa sawit yang masih dapat digunakan sebagai pupuk organik sehingga dapat dimanfaatkan untuk memenuhi ketersediaan unsur hara bagi tanah dan tanaman. Bahan organik yang telah terdekomposisi akan melepaskan senyawa-senyawa organik, baik itu berupa asam-asam organik ataupun kation-kation basa (Siregar et al., 2017). Bahan organik yang telah terdekomposisi akan menghasilkan ion $\mathrm{OH}^{-}$yang dapat menetralisir aktivitas ion $\mathrm{H}^{+}$. Asam-asam organik juga akan mengikat $\mathrm{Al}^{3+}$ dan $\mathrm{Fe}^{2+}$ yang dapat membentuk senyawa komplek (chelat), sehingga $\mathrm{Al}^{3+}$ dan $\mathrm{Fe}^{2+}$ tidak terhidrolisis kembali yang akan mengakibatkan peningkatan $\mathrm{pH}$ tanah.

\section{KESIMPULAN}

Interaksi antara genotipe F1 Kuning x Salung Pikit dan dan dosis pupuk organik TKKS 10 ton/ha menghasilkan jumlah anakan padi terbanyak. Genotipe F1 G3 (Kuning x Inpago 6) menghasilkan pertumbuhan dan hasil padi terbaik. Pada penelitian ini belum diperoleh titik optimum dosis pupuk organik TKKS terhadap pertumbuhan dan hasil lima genotipe yang diuji.

\section{UCAPAN TERIMA KASIH}

Ucapan terima kasih disampaikan kepada Ibu Reny Herawati yang telah mensupport penelitian ini melalui Hibah Kompetitif Nasional Penelitian Terapan Direktorat Riset dan Pengabdian Masyarakat, Kemristekdikti tahun 2019 (Nomor Kontrak.165/SP2H/LT/DRPM/ 2019).

\section{DAFTAR PUSTAKA}

Andri, S. Nelvia \& Saputra, S.I. (2016). Pemberian kompos TKKS dan Cocopeat pada tanah subsoil Ultisol terhadap pertumbuhan bibit kelapa sawit (Elaeis guineensis Jacq.) di pre nursery. Jurnal Agroteknologi, 7(1), 1-6.

Anhar, R., Erita, H. \& Efendi. (2016). Pengaruh dosis pupuk urea terhadap pertumbuhan dan produksi plasma nutfah padi lokal asal Aceh. Jurnal Kawista,1(1), 30-36.

Astiningrum, M. (2005). Manajemen Persampahan. Majalah Ilmiah Dinamika, Universitas Tidar Magelang, Magelang. 15 Agustus 2005.

Badan Pusat Statistik. (2020). Luas Panen, Produksi, dan Produktivitas Padi Menurut Provinsi, 20182019.https://www.bps.go.id/dynamictable/ 2019/04/15/1608/luas-panenproduksi-danproduktivitas-padi-menurut-provinsi2018.html. 1 Juni 2020.

Fitriatin, B. N., Yuniarti, A., Turmuktini, T. \& Ruswandi, F.K. (2014). The effect of phosphate solubilizing microbe producing growth regulators on soil phosphate, growth and yield of maize and fertilizer efficiency on Ultisol. Eurasian J. of Soil Sci. 1(1),101-107.DOI:htttps://10.18393/ejss. 34313.

Ginting, J., Damanik, B.S., Sitanggang, J.M. \& Muluk, C.(2015). Effect of shade,organic materials and varieties on growth and production of upland rice. International Journal of Scientific \& Technology Research, 4(1), 68-74.

Gusmiatun \& Marlina, N. (2018). Peran pupuk organik dalam mengurangi pupuk anorganik pada budidaya padi gogo. Jurnal Ilmiah Agribisnis dan Perikanan (Agrikan UMMU-Ternate), 11 (2), 91-99. 
Hayat, E.S. \& Andayani, S. (2014). Pengelolaan limbah tandan kosong kelapa sawit dan aplikasi biomassa Chromolaena odorata terhadap pertumbuhan dan hasil tanaman padi serta sifat tanah Sulfaquent. Jurnal Teknologi Pengelolaan Limbah (Journal of Waste Management Technology), 7(2), 44-51.

Hepriyani, A.D., Hidayat, K.F. \& Utomo, M. (2016). Pengaruh pemupukan nitrogen dan sistem olah tanah jangka panjang terhadap pertumbuhan dan produksi padi gogo (Oryza sativa L.) tahun ke-27 di Lahan Politeknik Negeri Lampung. J.Agrotek Tropika, 4(1), 36-42.

Herawati, R., Purwoko, B.S. \& Dewi, I.S. (2010). Characterization of doubled haploid derived from anther culture for new type upland rice. J. Agron. Indonesia,38(3),170-176.DOI: https://doi.org/ 10.24831/jai.v38i3.14244.

Herawati, R., Inoriah, E., Rustikawati \& Mukhtasar. (2017). Genetics diversity and agronomic characers of F3 lines selected by recurrent selection for drought tolerance and blast resistance of Bengkulu local rice varieties. International Journal on Advance Science Engineering Information Technology, 7(3), 922927. DOI:https://10.18517/ijaseit.7.3.1641.

Herawati, R., Masdar \& Alnopri. (2019). Correlations and path analysis to determine the selection characters for developing new-type of upland rice.BioScience Research, 16(2),14921499.

Herawati, R., Purwoko, B.S. \& Dewi, I.S. (2009). Keragaman genetik dan karakter agronomi galur haploid ganda padi gogo dengan sifatsifat tipe baru hasil kultur antera. J. Agron. Indonesia, 37(2), 87-94. DOI: https://doi.org/ 10.24831/jai.v37i2.1399.

Ikhwani \& Rustiati, T. (2018). Respons varietas padi dengan beras berkarakter khusus terhadap pemupukan dan cara tanam. Penelitian Pertanian Tanaman Pangan, 2(1), 17-24. DOI: http//dx. doi.org/10.21082/jpptp.v2n1.2018. p17-24.

Kasim, N. (2000). Eksudasi dan Akumulasi Asam Organik pada Beberapa Kedelai (Glycine $\max (\mathrm{L})$ Merr.) Genotipe Toleran Aluminium. Tesis. Program Pascasarjana Institut Pertanian Bogor, Bogor.

Kusumastuti, A. (2014). Soil available P dynamics, pH, organic-C, and P uptake of Patchouli (Pogostemon cablin Benth.) at various dosages of organic matters and phosphate in Ultisols. Jurnal Penelitian Pertanian Terapan, 14(3),145-151. DOI: https:// doi.org/10.25181/jppt.v14i3.153.

Makarim, A.K \& Suhartatik, E. (2006). Budidaya padi dengan masukan in situ menuju perpadian masa depan. Buletin Iptek Tanaman Pangan, 1(1), 19-29.

Mashfufah, L.F. \& Prasetya, B. (2019). Pengaruh abu terbang batubara, kompos tandan kosong kelapa sawit, dan mikoriza terhadap ketersediaan dan serapan fosfor, pertumbuhan dan produksi jagung pada ultisol. Jurnal Tanah dan Sumberdaya Lahan, 6(2), 1261-1272. DOI: http://dx.doi.org/10.21776/ub.jtsl.2019. 006.2.7.

Nazirah, L. \& Damanik, B.S.J. (2015). Pertumbuhan dan hasil tiga varietas padi gogo pada perlakuan pemupukan. Jurnal Floratek, 10(1), 5460.

Siregar, D., Marbun, P. \& Marpaung, P. (2013). Pengaruh varietas dan bahan organik yang berbeda terhadap bobot 1000 butir dan biomassa padi sawah Ip400 pada musim tanam I. Jurnal Online Agroekoteknologi, 4(1), 1413-1421.

Siregar, P., Fauzi \& Supriadi. (2017). Pengaruh pemberian beberapa sumber bahan organik dan masa inkubasi terhadap beberapa aspek kimia kesuburan tanah Ultisol. Jurnal Agroekoteknologi FP USU, 5(2), 256-264.

Sitinjak, H. \& Idwar. (2015). Respon berbagai varietas padi sawah (Oryza sativa L.) yang ditanam dengan pendekatan teknik budidaya jajar legowo dan sistem tegel. JOM Faperta, 2(2), 1-15.

Subekti, A. (2011). Adaptasi lima puluh genotipe padi gogo pada tiga lingkungan kemasaman tanah ultisol.Widyariset,14(2),285-293. DOI: http:// dx.doi.org/10.14203/widyariset.14.2.2011. 285-294.

Syahputra, E., Fauzi \& Razali. (2015). Karakteristik sifat kimia sub grup tanah ultisol di beberapa wilayah Sumatera Utara. JurnalAgroekoteknologi, 4(1), 1796-1803.

Syahputra, Idwar \& Tabrani, G. (2016). Respon beberapa varietas padi gogo (Oryza sativa L.) yang ditanam di tanah Ultisol terhadap amelioran. JOM Faperta, 3(1), 1-11.

Syahril, N.M., Nuraini,Y. \& Purwani, J. (2017). Pengaruh sianobakteri dan dosis pupuk nitrogen terhadap hasil padi sawah (Oryza sativa L.). Jurnal Tanah dan Sumberdaya Lahan, 4 (2), 599-608. DOI: https://doi.org/10.21776/ ub.jtsl.

Tan, K.H. (2010). Principles of Soil Chemistry Fourth Edition.CRC Press Tailor and Francis Group. Boca Raton, London.

Toiby, A.R, Rahmadani, E. \& Oksana. (2015). Perubahan sifat kimia tandan kosong kelapa sawit yang difermentasi dengan EM4 pada dosis dan lama pemeraman yang berbeda.Jurnal Agrotek 


\section{RESPON PERTUMBUHAN DAN HASIL LIMA GENOTIPE}

nologi, $\quad 6(1), 1-8 . \quad$ DOI: http://dx.doi.org/10. 24014/ja.v6il.1370.

Utama, M.Z.H., Haryoko, W., Munir, R. \& Sunadi. (2009). Penapisan varietas padi toleran salinitas pada lahan rawa, di Kabupaten Pesisir Selatan. $J$. Agron. Indonesia, 37, 101-106.
Utama, M.Z.H. (2008). Mekanisme fisiologi toleransi cekaman aluminium pada spesies legum penutup tanah terhadap metabolisme nitrat, amonium dan nitrit. Bul. Agron. 36(1), 175-179. 